\title{
STUDY KINEMATIKA GEL LIDAH BUAYA UNTUK MENGATASI WAJAH JERAWAT
}

\author{
Hafifah Azirah*1 \\ Fakultas Matematika Dan Ilmu Pengetahuan Alam \\ 'Pendidikan Kimia,FMIPA,Universitas Negeri Padang,Indonesia \\ *E-mail : hafifahazirah70@gmail.com
}

\begin{abstract}
ABSTRAK. Metode yang dilakukan adalah eksperimen dan uji aktivitas katalitik secara langsung. Tahapan pertama dilakukan dengan pembuatan gel lidah buaya. Uji aktivitas langsung dilakukan dengan variasi tiga kali selama satu minggu. Hasil eksperimen membuktikan bahwa gel lidah buaya dapat mengatasi wajah jerawat. Kondisi optimum gel lidah buaya tercapai pada pemakaian yang ketiga. Penyembuhan ini diduga karena aktivitas katalitik gel lidah buaya terhadap wajah jerawat.
\end{abstract}

\section{Kata kunci : reaksi kimia, katalitik, gel lidah buaya, wajah jerawat}

\section{PENDAHULUAN}

Reaksi $^{(24)}$ kimia sangat penting dalam kehidupan sehari-hari. Reaksi kimia ${ }^{(11)}$ adalah suatu proses dalam kehidupan yang akan menghasilkan perubahan. Tanpa adanya reaksi kimia dalam kehidupan sehari-hari iu tidaklah mungkin. Reaksi kimia bisa terjadi dimana-mana. Reaksi kimia dapat terjadi pada tumbuhan, buah-buahan ${ }^{(32)}$, hewan ${ }^{(29)}$ dan manusia. Misalnya pada tubuh ${ }^{(27,33)}$ manusia ${ }^{(28)}$ seperti pada mata, telinga, kaki, dan wajah. Dimana reaksi kimia itu sendiri merupakan suatu reaksi atau proses yang terdiri dari satu atau lebih zat yang bereaksi sehingga menghasilkan zat baru yang berbeda dengan zat sebelumnya ${ }^{(17)}$. Zat yang menjadi pereaksi disebut dengan reaktan sedangkan hasil reaksi disebut produk. Reaksi kimia dapat dilihat dari ciri-ciri dari reaksi kimia itu sendiri. Adapun ciri-ciri rekasi kimia yaitu adanya perubahan warna,perubahan suhu, perubahan ph, adanya endapan,dan adanya gelembung gas. Salah satu yang mempengarhi rekasi kimia adalah katalis.

Katalis atau katalik $^{(25)}$ merupakan suatu zat yang dapat mempercepat berlangsungnya suatu reaksi Tetapi tidak ikut serta bereaksi ${ }^{(12)}$. Katalis merupakan salah satu faktor yang mempengaruhi laju reaksi. Suatu reaksi dapat berjalan cepat atau 
lambat ${ }^{(30)}$ karena adanya suatu katalis. Hal tersebut karena reaksi kimia ${ }^{(15)}$ membutuhkan katalis $^{(26)}$ untuk mempercepat reaksi untuk membentuk hal yang baru. Katalis ${ }^{(13)}$ dan reaksi kimia $^{(14)}$ sangat berkaitan erat. Katalis sangat berperan dalam suatu reaksi. Katalis juga dapat menurunkan energi aktivasi. Katalis terbagi menjadi dua yaitu katalis homogen dan heterogen. Katalis asam seperti asam klorida, asam sitrat, asam oksalat dan katalis enzim yaitu inulinase $^{(18)}$. Asam laurat sebagai katalis dapat berperan sebagai anti bakteri, anti mikroba, dan anti jamur sehingga dapat mencegah infeksi tambahan pada saluran pernapasan yang tidak hanya bisa disebabkan oleh virus ${ }^{(35)}$ namun juga yang diakibatkan oleh bakteri ${ }^{(31)}$.

Dalam kehidupan kita sehari-hari banyak ditemukan katalis, baik katalis alami ${ }^{(16)}$ maupun katalis buatan yang terdapat di laboratorium kimia. Katalis terdapat pada tumbuhan seperti bahan alami dan anorganik. Salah satu contoh tumbuhan yang ada katalisnya adalah tanaman lidah buaya. Obot-obat tradisional pada umumnya berasal dari tumbuh-tumbuhan yang banyak tumbuh di lingkungan tempat tinggal masyarakat ${ }^{(20)}$. Katalis pada tumbuhan biasanya terdapat pada daun dan akar, contohnya daun salam dan lidah buaya.

Lidah buaya (Aloe vera) merupakan tanaman asli Afrika, yang termasuk golongan Liliaceae. Berkembangnya ilmu pengetahuan dan teknologi sekarang ini, memperluas pemanfaatan khasiat lidah buaya ${ }^{(6)}$. Tanaman lidah buaya banyak dijumpai di indonesia. Tanaman ini sering dijumpai di pekarangan rumah. Tanaman lidah buaya ini mudah hidup di iklim tropis dan subtropis. Tanaman lidah buaya (Aloe vera) merupakan salah satu komoditas pertanian daerah tropis yang mempunyai peluang sangat besar untuk dikembangkan di Indonesia sebagai usaha agribisnis dengan prospek yang cukup menjanjikan ${ }^{(8)}$. Lidah buaya (Aloe vera (L.) Weeb.) merupakan satu dari 10 jenis tanaman terlaris di dunia yang berpotensi besar untuk dikembangkan sebagai tanaman obat dan bahan baku industri ${ }^{(9)}$. Khasiat tumbuhan sebagai obat terkait dengan kandungan senyawa metabolit sekunder yang terdapat pada tumbuhan tersebut ${ }^{(22)}$. Salah satu contohnya Beras ketan hitam merupakan salah satu jenis beras yang mengandung senyawa metabolit sekunder seperti: alkaloid, flavonoid, tannin dan steroid ${ }^{(23)}$.Lidah buaya juga dapat tumbuh di daerah yang dingin dan kering. Lidah buaya merupakan sejenis tanaman berduri. Tanaman ini terdiri dari akar, batang, dan daun. Akar lidah buaya tidak tumbuh ke dalam 
melainkan tumbuh ke samping. Batang lidang buaya tidak begitu besar dan tidak pula begitu kecil. Batang lidah buaya relatif pendek. Daun lidah buaya mempunyai bentuk yang sama dan saling berhadapan. Apabila daun lidah buaya ini di iris maka akan mengeluarkan cairan lendir. Cairan ini yang paling dominan di dalam lidah buaya. Cairan ini dinamakan dengan gel lidah buaya. Lidah buaya memiliki banyak manfaat. Salah satunya untuk wajah $^{(1)}$. Lidah buaya (Aloe vera) merupakan salah satu tanaman obat yang banyak digunakan dalam industri farmasi, terutama dalam sediaan $\operatorname{kosmetik}^{(7)}$. Pemilihan alternatif lidah buaya sebagai biokoagulan karena lidah buaya merupakan tanaman yang dapat tumbuh dengan mudah, sehingga tidak menyulitkan untuk pembudayaannya dalam skala $\operatorname{besar}^{(10)}$.

Wajah merupakan hal yang paling sensitif bagi diri seseorang. Dari wajah seseorang, orang lain dapat menilai kepribadian seseorang. Wajah dapat menunjukkan identitas seseorang. Melalui wajah seseorang dapat mengekspresikan apa yang ia rasakan. Oleh sebab itu seseorang sangat memperhatikan penampilannya terutama masalah wajah. Seseorang tidak enggan mengeluarkan banyak uang demi mendapatkan wajah yang bagus. Seseorang rela melakukan berbagai macam perawatan untuk wajah baik itu perawatan untuk wajah berminyak, wajah jerawat ${ }^{(2)}$, mencerahkan wajah, melembabkan wajah dan lain sebagainya.

Seseorang yang memiliki wajah berjerawat tidak akan tampil dengan percaya diri. Wajah berjerawat dapat diatasi dengan berbagai cara. Salah satu cara yang dapat digunakan untuk mengatasi wajah berjerawat yaitu dengan menggunakan lidah buaya. Lidah buaya dapat diolah. Hasil olahan lidah buaya salah satunya berupa gel lidah buaya yang dapat digunakan untuk mengatasi dan mengobati jerawat serta mencerahkan dan melembabkan kulit wajah. Cara menggunakan gel lidah buaya untuk wajah jerawat dapat dengan mengoleskan ke wajah sebagai masker ${ }^{(3)}$.

\section{METODE}

Metode ini berisi atas 3 hal yaitu:

Alat dan bahan

Peralatan yang di pakai adalah pisau (cutter), gunting tailor, sendok makan (dool), mangkok (cantiks), satu set tempat masker (Diy). 
Bahan yang digunakan adalah lidah buaya yang diambil di Padang besi, Sawah liek no 6 Padang.

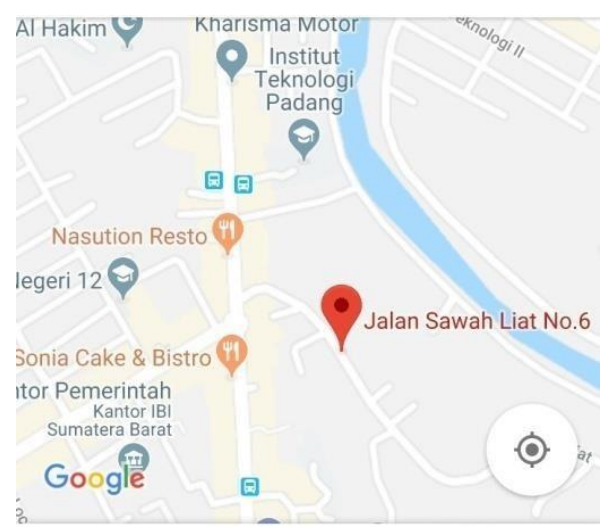

Prosedur kerja

1. Penyiapan Sampel

Sampel ( lidah buaya ) di ambil di lokasi Padang besi, Sawah liek no 6 Padang. Sampel diambil dan dipotong sebanyak 2 sampai 3 daun lidah buaya. Sampel ( lidah buaya) yang diambil dicuci dan bersihkan resin dari daun dengan meletakkannya di dalam mangkok selama 10 menit.

2. Pembuatan Gel Lidah Buaya

- Mengupas sampel ( daun lidah buaya ) yang sudah dicuci dan di bersihkan dengan pisau

- Mengambil gel dengan menggunakan sendok

- Pastikan semua gel sudah terkorek

- Letakkan di dalam tempat masker

- Kocok gel dengan menggunakan garpu

- Gel siap digunakan

- Oleskan gel pada wajah menggunakan kuas secara merata

- Biarkan gel sampai kering 
- Bersihkan wajah dengan air bersih

3. Pengujian Gel lidah buaya

Gel yang sudah jadi diuji cobakan kepada seseorang. Menurut pendapatnya gel tersebut dapat mengurangi jerawat pada wajahnya . juga dapat membantu mencerahkan serta dapat melembabkan wajah. Jadi gel ini mempunyai banyak manfaat. Selain praktis untuk dilakukan dan sampel yang digunakan juga mudah di dapat.

Metode ini dapat dibuat sebagai berikut:
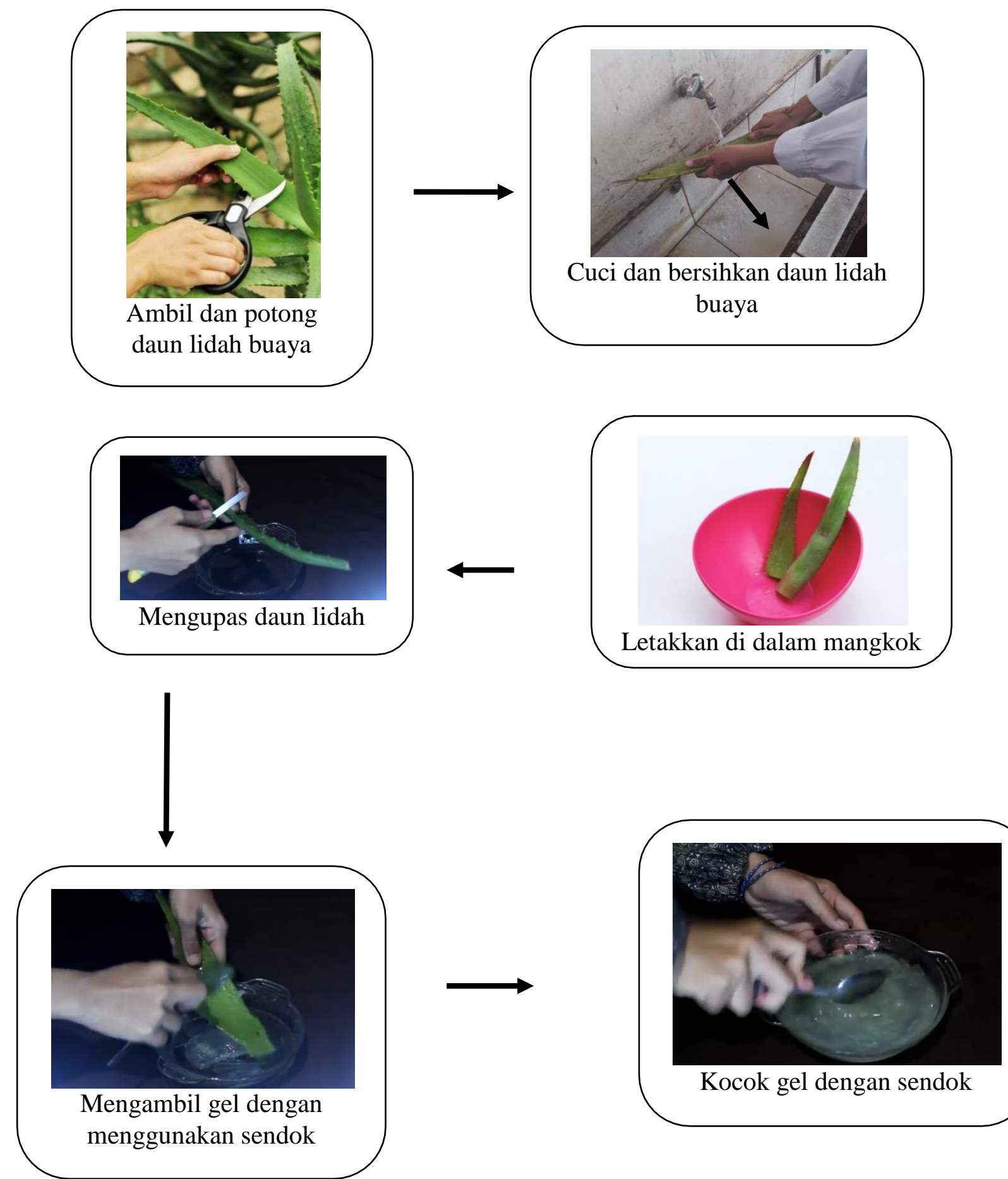

Kocok gel dengan sendok 

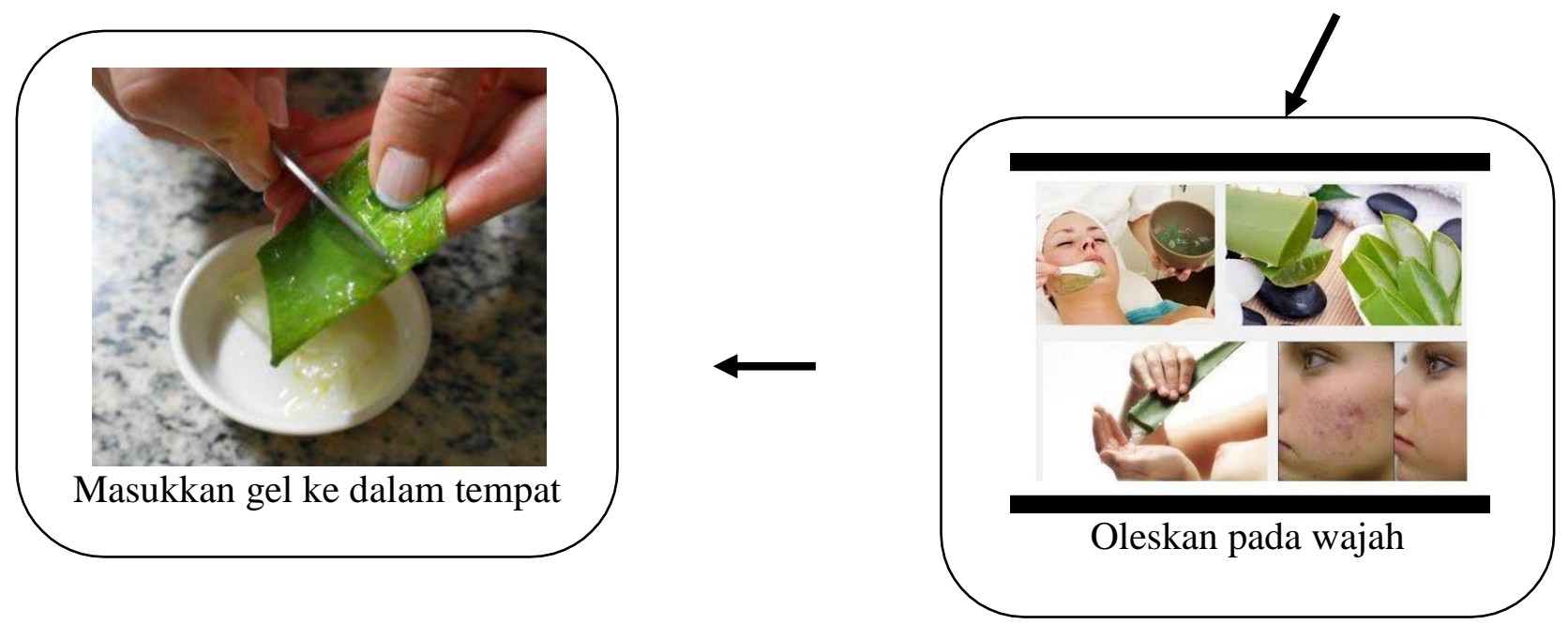

\section{Hasil Pembuatan}

Hasil pembuatan gel lidah buaya diperoleh sebanyak 2 sampai 3 sendok makan. Hal ini dapat dilihat dari gambar berikut ini:

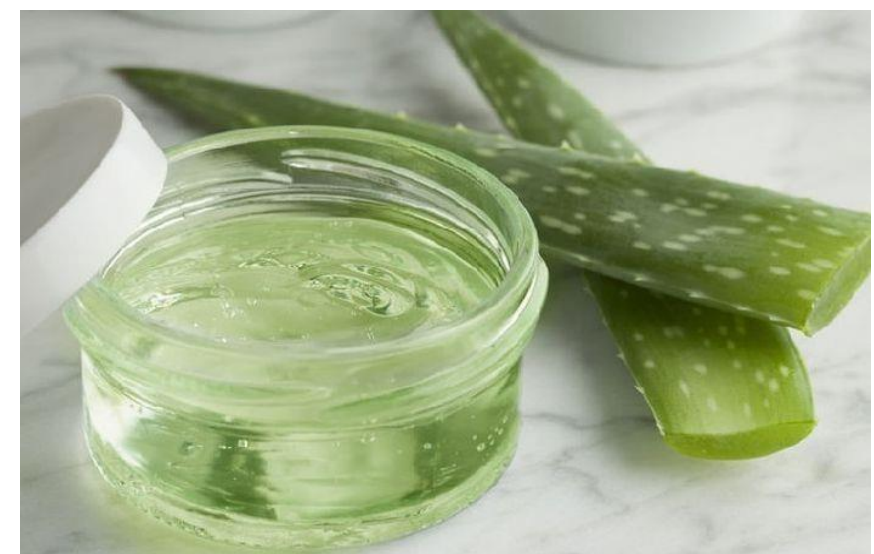

\section{Hasil Uji Coba}

Pengujian dilakukan terhadap seseorang ternyata hasilnya berhasil. Dengan gel lidah buaya dapat mengatasi wajah jerawat serta membantu melembabkan dan mencerahkan wajah.

\begin{tabular}{|l|l|l|}
\hline No & \multicolumn{1}{|c|}{ Waktu Pemakaian } & \multicolumn{1}{c|}{ Reaksi yang Terjadi } \\
\hline 1 & Pemakaian pertama & $\begin{array}{l}\text { Jerawat menjadi kering, jerawat memerah, volume } \\
\text { jerawat membesar }\end{array}$ \\
\hline 2 & Pemakaian kedua & Jerawat mulai mengecil dan mengelupas \\
\hline
\end{tabular}




\begin{tabular}{|l|l|l|}
\hline 3 & Pemakaian ketiga & Jerawat mulai berkurang dan tidak tampak \\
\hline
\end{tabular}

\section{PEMBAHASAN}

Pembuatan gel lidah buaya sangat mudah dilakukan. Karena bahan dan alat yang digunakan mudah di dapat. Dalam proses pembuatan gel lidah buaya tentu ada kendala dalam proses pembuatannya. Hanya saja kendala itu tidak banyak. Diantara kendala dalam proses pembuatan gel lidah buaya yaitu gel lidah buaya itu sifatnya tidak tahan lama. oleh sebab itu gel yang dibuat hanya secukupnya.dan hanya bisa dipakai untuk satu kali pemakaian. Apabila hendak menggunakan gel untuk pemakaian yang kedua kalinya otomatis gel harus dibuat yang baru. Kemudian dalam pengambilan daun lidah buaya harus hati-hati karena pada bagian tepi lidah buaya terdapat duri. Kemudian di dalam daun lidah buaya ini terdapat resin yang berwarna kuning gelap. Resin ini harus benar- benar dibersihkan. Apabila resin ini masih belum hilang maka akan mengakibatkan iritasi.

Hasil gel lidah buaya yang telah dibuat, diuji cobakan kepada seseorang. Dimana uji coba ini dilakukan untuk mengetahui apakah gel lidah buaya dapat mengatasi jerawat serta melembabkan dan mencerahkan wajah. Percobaan ini dilakukan dengan cara, mengambil daun lidah buaya dengan menggunakan gunting sebanyak 2-3 buah daun lidah buaya. Kemudian daun yang sudah diambil dicuci dan dibersihkan. Selanjutnya letakkan daun yang sudah dicuci kedalam mangkok untuk menghilangkan resin yang ada pada daun lidah buaya sselama 10 menit. Setelah itu kupas daun lidah buaya dengan menggunakan pisau. Usahakan mengupasnya hanya pada satu sisi kulit. Hal ini bertujuan agar gel lidah buaya tetap menempel pada sisi kulit yang lainnya. Kemudian ambil gel lidah buaya dengan menggunakan sendok . pastikan gel sudah terambil semuanya. Lalu di masukkan kedalam mangkok. Kocok gel yang ada di dalam mangkok dengan menggunakan garpu supaya gel yang didapat memiliki struktur yang halus. Pindahkan gel kedalam tempat masker. Gel lidah buaya siap digunakan.

Dalam pemakaian gel lidah buaya ini sebaiknya dilakukan tiga kali dalam seminggu. Cara pemakainnya cuci wajah dengan air bersih kemudian di keringkan dan setelah iu diolesi gel lidah buaya ke wajah dengan menggunakan kuas masker. Biarkan sampai mengering. Setelah kering cuci wajah dengan air bersih. Setelah pemakaian gel lidah buaya yang pertama, efek yang ditimbulkan yaitu jerawat menjadi kering dan 
memerah. Ukuran jerawat pun bertambah besar. Kemudian pada saat pemakaian yang kedua jerawat yang tadinya membesar sekarang mengecil dan jerawat mulai mengelupas dari wajah. Untuk mengoptimalkannya dilakukan pemakaian yang ketiga kalinya. Hasilnya jerawat mulai hilang dan tidak tampak lagi serta melembabkan dan mencerahkan kulit wajah. Ternyata uji coba yang dilakukan terbukti. Gel lidah buaya dapat mengatasi jerawat serta melembabkan dan mencerahkan kulit wajah. lidah buaya memiliki khasiat membuat kulit tidak cepat kering dan berfungsi sebagai pelembab ${ }^{(5)}$. Hal ini dikarenakan adanya kandungan zat dalam gel lidah buaya.

Pada daun lidah buaya terdapat tanin, fenol dan saponin. Tumbuhan yang digunakan sebagai bahan baku obat berkaitan erat dengan kandungan kimia yang terdapat didalamnya terutama senyawa bioaktif ${ }^{(19)}$.Senyawa bioaktif lainnya yang terkandung di dalam gel lidah buaya adalah glukomannan dan saponin yang dapat berperan sebagai antimikroba dan mampu menyembuhkan luka pada jaringan buah ${ }^{(4)}$.Gel lidah buaya juga mengandung lignin, saponin,tanin dan aloctin. Tanin memiliki sifat antibakteri dengan cara mempresipitasi protein. Tanin merupakan senyawa organik yang terdiri dari campuran senyawa polifenol kompleks. Tanin memiliki aktivitas antioksidan menghambat pertumbuhan tumor dan enzim. Tanin juga mempunyai antiseptik ysng dapat mencegah kerusakan yanag diakibatkan oleh bakteri atau jamur. Lignin berfungsi untuk memudahkan peresapan jel ke kulit sehingga mampu melindungi kulit dari dehidrasi dan melembabkan kulit. Saponin berfungsi sebagai antiseptik dan bahan pencuci yang baik seperti sabun.

Di dalam daun lidah buaya juga terdapat kompleks antrakuinon aloin, barbaloin, isobarbaloin,athranol, aloemodin, asam sinamat, asam krisopanat, asam glutamat, asam malat, asam suksinat, asam uronat,asam galakturonat, dan reistanol yang merupakan senyawa antimikroba dan mempunyai kandungan antibiotik. Ada juga enzim oksidase, amilase, katalase, lipase, dan protease yang berfungsi untuk menyembuhkan luka dan menghilangkan rasa nyeri pada luka.kemudian asam krisofan yang berfungssi sebagai pendorong penyembuhan kulit yang mengalami kerusakan. Selain itu juga terdapat vitamin $\mathrm{C}^{(34)}$, E, B1,B2,B6, Niacinida,Cholin,Asam Folat, dan betakaroten dalam lidah buaya yang berkhasiat sebagai antioksidan. Antioksidan menghambat reaksi oksidasi dan mencegah kerusakan sel dengan cara mengikat radikal bebas danmolekul yang sangat reaktif ${ }^{(21)}$.Ada juga mineral seperti $\mathrm{Ca}, \mathrm{K}, \mathrm{Na}, \mathrm{Mg}, \mathrm{Zn}, \mathrm{Cu}$,dan $\mathrm{Cr}$. Selain itu juga terdapat asam amino 
seperti lysine, threonine, valin, methionin,leusin,isoleusin dan fenilalanin.

Dari uraian kandungan yang terdapat pada lidah buaya tersebut, terbukti bahwa lidah buaya banyak memiliki manfaat. Salah satu manfaatnya yaitu dapat mengatasi dan megobati jerawat serta dapat melembabkan dan mencerahkan kulit wajah. Hal ini bisa terjadi karena aktivitas katalitik yang terdapat pada lidah buaya. Adapun kandungan senyawa yang terdapat pada lidah buaya yang berperan dalam mengatasi dan mengobati jerawat adalah mukopolisakarida, enzim, vitamin A,B, C, E, asam folat, mineral Zn dan Ca. Vitamin kholin bekerja lebih cepat dalam mengatasi atau mengobati jerawat. Dimana kholin berfungsi untuk membersihkan kulit dan sumber nutrisi bagi kulit sehingga dapat menyembuhkan jerawat dan melembabkan juga mencerahkan kulit wajah.

\section{Grafik Pengujian Gel Lidah Buaya}

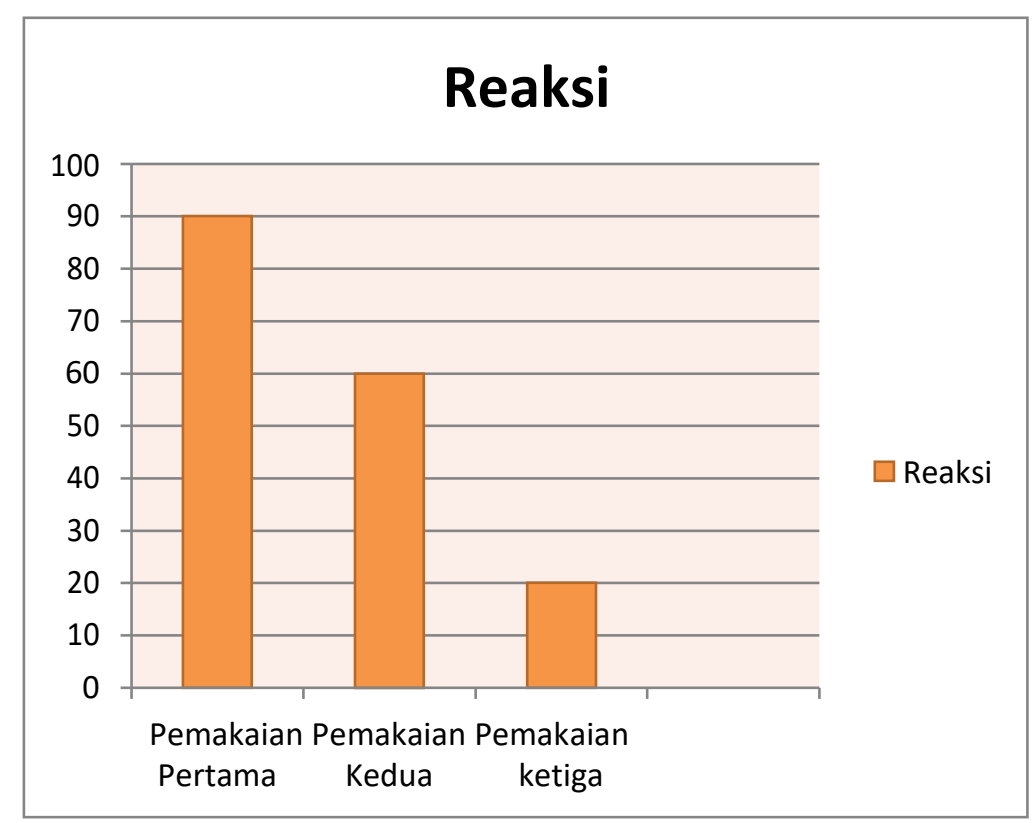

\section{KESIMPULAN}

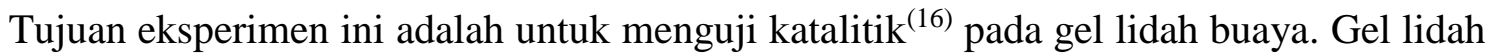
buaya dapat dibuat dengan mudah. Gel lidah buaya dapat mengatasi dan mengobati jerawat serta dapat mencerahkan dan melembabkan kulit wajah. Hal ini karena aktivitas katalitik gel lidah buaya terhadap wajah jerawat. Katalitik ada dalam kandungan yang terdapat pada gel lidah buaya.Gel lidah buaya mengandung tanin, lignin, saponin, fenol, mukopolisakarida, enzim, vitamin A,B, C, E , asam folat, mineral Zn , Ca,dan Vitamin 
kholin dan lain- lain. Dari hasil uji coba gel lidah buaya terbukti dapat mengatasi dan mengobati wajah jerawat serta mencerahkan dan melembabkan kulit wajah.

\section{REFERENSI}

(1) $\underline{\text { Ida, Nur }}$,Noer, Sitti Fauziah . 2008. Uji Stabilitas Fisik Gel Ekstrak Lidah Buaya (Aloe Vera L.) Majalah Farmasi Dan Farmakologi. Vol 16, No 2

(2) Nazir, Farhan, Zahari, Asril, Anas, Eliza.2015. Pengaruh Pemberian Gel Lidah Buaya (Aloe vera) Terhadap Jarak Pinggir Luka pada Tikus Wistar. Jurnal Kesehatan Andalas. Vol 4, No 3

(3) Widiawati, Wahyu, Lutfiati, Dewi. 2014. Perbedaan Hasil Penyembuhan Kulit Wajah Berjerawat Antara Masker Lidah Buaya Dengan Masker Non Lidah Buaya. Jurnal Tata Rias. Vol 3, No 01

(4) Aminudin Dan Nawangwulan. 2014. Pengaruh Edible Coating Gel Lidah Buaya (Aloe Vera Linne) Terhadap Mutu Dan Umur Simpan Mentimun (Edible Coating Influence OF Aloe Vera Gel To Quality Cucumber And Self Life). Ekologia, Vol. 14 No.1, April 2014: $1-12$

(5) Erliza Hambali, Ani Suryani, Dan Evimia Indriani Umiarti. 2014. Kajian Pengaruh Penambahan Lidah Buaya (Aloe Vera) Terhadap Mutu Sabun Transparan. J. Tek. Ind. Pert. Vol. 14(2), 74-79

(6) Ani Suryani, Erliza Hambali, Dan Hasanah Kurniadewi. 2015. Kajian Penggunaan Lidah Buaya (Aloe Vera) Dan Bee Pollen Pada Pembuatan Sabun Opaque. J. Tek. Ind. Pert. Vol. 15(2), 40-45

(7) Tri Yuni Hendrawati, Eriyatno, Machfud, Koesnandar, Illah Sailah Dan Titi Candra Sunarti. 2017. Rancang Bangun Industri Tepung Lidah Buaya (Aloe Vera) Terpadu. J. Tek. Ind. Pert. Vol. 17(1),12-22

(8) Iwan Sasli1, Sudirman Yahya, Sudradjat, Yadi Setiadi dan Sudarsono. 2008. Perbaikan Pertumbuhan dan Kualitas Tanaman Lidah Buaya di Tanah Gambut dengan Aplikasi Mikoriza Arbuskula dan Pemupukan. Bul. Agron. (36) (3) 248 - 254

(9) Jumini dan Syammiah. 2006. Pengaruh Jenis Pupuk Organik Dan Jarak Tanam Terhadap Pertumbuhan Lidah Buaya. J. Floratek 2 :107 - 113 
(10) Mujariah, Paulus Hengky Abram, dan Minarni Rama Jura. 2016. Penggunaan Gel Lidah Buaya (Aloe Vera) Sebagai Koagulan Alami Dalam Penjernihan Air Sumur Di Desa Sausu Tambu Kecamatan Sausu . J. Akademika Kim. 5(1): 16-22, February 2016. ISSN 2302-6030 (p), 2477-5185 (e).

(11) Zainul, R., \& Prima, C. B. (2018, December 9). Teknologi Material Maju Prinsip Dasar Dan Aspek Rekayasa. tps://doi.org/10.31227/osf.io/p63wc

(12) M., Sanjaya, H., \& Zainul, R. 2018. Characterization of napa soil and adsorption of $\mathrm{Pb}$ (II) from aqueous solutions using on column method. https://doi.org/10.31227/osf.io/t8fh9

(13) Liza, Y. M., Yasin, R. C., Maidani, S. S., \& Zainul, R. 2018. Sol Gel : Principle And Technique (A Review). https://doi.org/10.31227/osf.io/2cuh8

(14) Chairi, I., E., \& Zainul, R. 2018. Pengembangan LKS dengan Pendekatan Saintifik Berbasis Discovery Learning Pada Materi Hukum Dasar Kimia untuk Pembelajaran Kelas X SMA/MA.

(15) Zainul, R. 2018. Design and Modification of Copper Oxide Electrodes for Improving Conversion Coefficient Indoors Lights (PV-Cell) Photocells. https://doi.org/10.31227/osf.io/pgn84

(16) Hidayani, T. 2018. Grafting Polipropilena Dengan Maleat Anhidrida Sebagai Pengikat Silang Dengan Inisiator Benzoil Peroksida, EKSAKTA: Berkala Ilmiah Bidang MIPA, 19(1), pp. 56-62. doi: 10.24036/eksakta/vol19-iss1/127

(17) Badrulfalah B, Irianingsih I, Joebaedi K. 2018. Some Operations On Mixed Monotone Operator In Banach Spaces.Eksakta Berkala Ilmiah Bidang Mipa.Vol 19 No 2 (2018).Doi: 10.24036/Eksakta/Vol19-Iss2/150

(18) Hevi Horiza, dkk. 2017. Ekstraksi Dan Karakterisasi Inulin Dari Umbi Dahlia (Dahlia Sp.L) Segar Dan Disimpan. Eksakta Vol. 18 No. 1, April 2017 http://eksakta.ppj.unp.ac.id

(19) Suryelita. 2017. Isolasi Dan Karakterisasi Senyawa Steroid Dari Daun Cemara Natal (Cupressus Funebris Endl.) Eksakta Vol. 18 No. 1, April 2017. http://eksakta.ppj.unp.ac.id 
(20) Nadayatul Khaira Huda, dkk. 2017. Pengaruh Ekstrak Sambiloto (Andrographis Paniculata Nees.) Terhadap Siklus Estrus Mencit (Mus Musculus L. Swiss Webster) Eksakta Vol. 18 No. 2, Oktober 2017. http://eksakta.ppj.unp.ac.id

(21) Ayu Nirmala Sari . 2017. Potensi Antioksidan Alami Pada Ekstrak Daun Jamblang (Syzigium Cumini (L.) Skeels). Eksakta Vol. 18 No. 2, Oktober 2017. http://eksakta.ppj.unp.ac.id.

(22) Melindra Mulia. 2017. Isolasi Kumarin Dari Kulit Buah Limau Sundai (Citrus Nobilis Lour). Eksakta Vol. 18 No. 2, Oktober 2017 http://eksakta.ppj.unp.ac.id

(23) Iryani, dkk. 2017. Uji Aktivitas Anti Diabetes Mellitus Senyawa Metabolit Sekunder Fraksi Air Dari Beras Ketan Hitam ( Oryza Satival. Var Glutinosa) Pada Mencit Putih. Eksakta Vol. 18 No. 1, April 2017. http://eksakta.ppj.unp.ac.id

(24) Ruswandi, R. 2018. Determination of Fructose Content resulted by Inulin Hydrolysis with DNS as Oxidizer", EKSAKTA: Berkala Ilmiah Bidang MIPA, 19(1), pp. 14-23. doi: 10.24036/eksakta/vol19-iss1/102.2018.

(25) Hidayani, T. 2018. Grafting Polipropilena Dengan Maleat Anhidrida Sebagai Pengikat Silang Dengan Inisiator Benzoil Peroksida, Eksakta: Berkala Ilmiah Bidang MIPA, 19(1), pp. 56-62. doi: 10.24036/eksakta/vol19-iss1/127

(26) Sanjaya, H. 2017. Degradasi Methylene Blue Menggunakan Katalis Zno-Peg Dengan Metode Fotosonolisi. EKSAKTA: Berkala Ilmiah Bidang MIPA, 18(02), pp. 21-29. doi: 10.24036/eksakta/vol18-iss02/45

(27) Sari, A. 2017. Potensi Antioksidan Alami Pada Ekstrak Daun Jamblang (Syzigium Cumini (L.) Skeels). EKSAKTA: Berkala Ilmiah Bidang MIPA, 18(02), pp. 107-112. doi: 10.24036/eksakta/vol18-iss02/61

(28) Yanuar, F., Tillah, M. and Devianto, D. 2018. Modeling of Human Development Index Using Ridge Regression Method. EKSAKTA: Berkala Ilmiah Bidang MIPA, 19(2), pp. 1-11. doi: 10.24036/eksakta/vol19-iss2/134

(29) Sumarmin, R., Yuniarti, E. and Razak, A. 2017. Kualitas Sperma Ejakulat Pejantan Ayam Kukuak Balenggek Pada Pengandangan Tunggal Terisolasi (Ejaculated Sperm Quality of Isolated Single Caging of Balenggek Chickens). EKSAKTA: Berkala Ilmiah Bidang MIPA, 18(01), pp. 40-45. doi: 10.24036/eksakta/vol18-iss01/15 
(30) Sanjaya, H. 2017. Degradasi Methylene Blue Menggunakan Katalis Zno-Peg Dengan Metode Fotosonolisis. EKSAKTA: Berkala Ilmiah Bidang MIPA, 18(02), pp. 21-29. doi: 10.24036/eksakta/vol18-iss02/45

(31) Zainul, R. (2018, August 16). Effect of Temperature and Particle Motion against the ability of $\mathrm{ZnO}$ Semiconductor Photocatalyst in Humic Acid. https://doi.org/10.31227/osf.io/wnygb

(32) Zainul, R., Alif, A., Aziz, H., \& Arief, S. 2015. Disain Geometri Reaktor Fotosel Cahaya Ruang. Jurnal Riset Kimia, 8(2), 131 . https://doi.org/10.25077/jrk.v8i2.230

(33) Anhar, A., Sumarmin, R., \& Zainul, R. 2016. Measurement of Glycemic Index of West Sumatera Local Rice Genotypes for Healthy Food Selection. Journal of Chemical and Pharmaceutical Research, 8(8), 1035-1040 . https://doi.org/10.31227/osf.io/tgy8h

(34) Alfionita, T., \& Zainul, R. (2019, January 29). Calcium Chloride (CaCl2) : Characteristics and Molecular Interaction in Solution. https://doi.org/10.31227/osf.io/m37xi

(35) Yuliani, F., \& Zainul, R. (2018, November 13). Analisis Termodinamika Molekul Magnesium Sulphate (MgSO4). https://doi.org/10.31227/osf.io/uxz4y 